\title{
ПРЯНЫЕ И АРОМАТИЧЕСКИЕ РАСТЕНИЯ В ПСИХИАТРИИ И НЕВРОЛОГИИ: НАУЧНЫЙ ОБЗОР. ЧАСТЬ I.
}

\author{
Беккер Р.А., Быков Ю.В.
}

Цель исследования: Представить читателю подробный исторический обзор о применении пряных и ароматических растений в психиатрии и неврологии, а также данные современных исследований об их эффективности в терапии различных психических и психосоматических патологий, нейродегенеративных заболеваний.

Методология проведения работы: В качестве начальной отправной точки для нашей работь мы взяли список всех применяемых в кулинарии различных народов специй и приправ из английской Википедии, как один из наиболее полных подобных списков в Интернете (en.wikipedia.org/wiki/List of_spices). Затем мы изучили современную доказательную базу и исторические данные о применении каждого из упомянутых в данном списке растений, используя поисковые системы PubMed, Google Scholar, Science Direct, Web of Science, и представили найденные данные в настоящем обзоре.

Результаты: Полученные нами в результате составления настоящего обзора данные свидетельствуют о значительном терапевтическом потенциале многих пряных и ароматических растений в психиатрии и неврологии, в особенности в лечении лёгких форм тревожных и депрессивных расстройств, лёгких когнитивных нарушений, а также в лечении таких психосоматических заболеваний, как синдром раздражённого кишечника, мигрень, синдром предменструального напряжения, климактерические расстройства. Доказательная база для применения в психиатрии и неврологии разных пряных и ароматических растений различна по качеству. Для одних пряных и ароматических растений и извлечённых из них биологически активных веществ пока существуют лишь данные экспериментов на животных в сочетании с эмпирическим опытом народной медицины, для других - имеются предварительные обнадёживающчие результаты открытых пилотных исследований на человеке, для третьих, таких, как куркумин, сафранал-положительные результаты 
небольших рандомизированных клинических испьтаний. Важно, однако, то, что исследование психотропного и нейротропного потенииала пряных и ароматических растений, судя по количеству публикаций именно в последние годы (2013-2017), рассматривается как одно из перспективных направлений для поиска новых антидепрессантов, анксиолитиков и антидементных препаратов.

Область применения результатов: Полученные нами результаты дают теоретические и практические основания для применения экстрактов из некоторых пряных и ароматических растений, таких, как куркумин, сафранал, пиперин, эфирное масло лаванды, в лечении лёгких форм тревожных и депрессивных состояний, лёгких когнитивных нарушений, особенно у пачиентов, отказывающихся от фармакотерапии или плохо её переносящих.

Ключевые слова: пряности; пряные растения; ароматические растения; история психиатрии; шафран; анис; бадьян; черный переи; имбирь; ваниль; куркума; кумин; кориандр; корица; базилик; тимьян; пажитник; сельдерей; манго; лук; чеснок; горчииа; мелисса; шалфей; кожура ичитрусовых; розовые лепестки; пачули; депрессивные расстройства; тревожные расстройства; когнитивные нарушения.

\section{THE SPICY AND AROMATIC HERBS IN PSYCHIATRY AND NEUROLOGY: SCIENTIFIC REVIEW. PART I.}

\section{Bekker R.A., Bykov Yu.V.}

Purpose: To give the reader a detailed historical overview of the application of spicy and aromatic herbs in the field of psychiatry and neurology, as well as modern data from clinical and preclinical studies on their effectiveness in the therapy of various mental and psychosomatic pathologies, and neurodegenerative diseases.

Methodology: As an initial starting point for our work, we took a list of all the spices and aromatic herbs used in culinary of various nations from English Wikipedia, as it is one of the most complete of such lists on the Internet (en.wikipedia.org/wiki/List_of_spices). We then examined the current evidence base and historical data on the use of each of the listed plants using the PubMed, Google Scholar, Science Direct, Web of Science search engines, and presented our findings in this review. 
Results: The data we have presented in this review clearly shows that there is a significant therapeutic potential for many spicy and aromatic herbs in both psychiatry and neurology, especially in the treatment of mild anxiety and depressive disorders, mild cognitive impairment, and in the treatment of psychosomatic diseases such as irritable bowel syndrome, migraine, premenstrual tension syndrome, climacteric disorders. The evidence base for use in psychiatry and neurology of different spicy and aromatic herbs is very different in quality. For some spicy and aromatic herbs and biologically active substances extracted from them, only animal data, combined with empirical experience of traditional medicine, exist for the time being, for others - there are preliminary encouraging results of open pilot studies on humans, for others, such as curcumin, safranal - there are positive results from small randomized clinical trials. It is important, however, that the study of the psychotropic and neurotropic potential of spicy and aromatic herbs, judging by the number of publications in recent years (2013-2017), is considered as one of the promising directions for the search for new antidepressants, anxiolytics and anti-dementia drugs.

Practical implications: The results that we have presented in this review, give theoretical and practical reasons for the use of extracts from some spicy and aromatic herbs, such as curcumin, safranal, piperine, lavender essential oil, in the treatment of mild forms of anxious and depressive states, mild cognitive impairment, especially in patients who refuse traditional psychopharmacotherapy, or for those who are totally unable to tolerate traditional psychopharmacotherapy or poorly tolerate it.

Keywords: Spices; spicy herbs; aromatic herbs; history of psychiatry; saffron; anise; star anise; black pepper; ginger; vanilla; turmeric; cumin; coriander; cinnamon; basil; thyme; fenugreek; celery; mango; onion; garlic; mustard; lemon balm; sage; citrus peel; rose petals; patchouli; depressive disorders; anxiety disorders; cognitive impairment.

\section{Введение \\ (Общие исторические сведения)}

На протяжении тысячелетий человечество пыталось эмпирически применять различные пряные и ароматические растения не только в кулинарии, но и в качестве лекарственных растений при самых разных заболеваниях и патологических состояниях, в том числе и нервно-психических. За первыми попытками применения пряных и ароматических растений в качестве лекарственных стояла донаучная, старая как мир, идея: если какое-либо растение оказывает столь сильное раздражающее влияние 
на наши вкусовые и обонятельные рецепторы, на наши слизистые оболочки, на наш ЖКТ и его пищеварительные железы, а нередко и на кожу (как, например, горчица, жгучий перец), то не может ли это растение оказывать какой-либо эффект и на другие органы и системы организма? Не может ли оно в результате помогать при каких-либо заболеваниях или патологических состояниях, в том числе и при «нервных» или душевных болезнях? С другой стороны, была не менее популярна и идея о том, что столь сильно пахнущие и имеющие такой яркий, выраженный вкус растения могут также и сильно навредить, причём не только людям, страдающим проблемами с ЖКТ, но и людям с нервными и душевными расстройствами [Healy D., 2004].

Так, ещё Филипп Пинель, основоположник современной гуманистической психиатрии и «моральной терапии», полагал, что пища для больных с «острыми умственными помешательствами» (то есть с тем, что мы бы сегодня назвали острыми психозами) должна быть достаточно пресной, лишенной пряностей, а также не содержащей излишков кислоты, соли и сахара. Это укладывалось в общую концепцию Ф. Пинеля о целесообразности «щадящего» режима, ограничения всяких излишних сенсорных стимулов для таких островозбуждённых, дезорганизованных, неадекватно себя ведущих больных. В рамках этой же концепции Ф. Пинель создавал для таких больных специальные тихие, затемнённые, шумоизолированные (обитые войлоком по полу и стенам) комнаты, запрещал персоналу слишком много общаться с этими больными, раздражать их [Healy D., 2004].

C другой же стороны, Ф. Пинель также считал необходимым и целесообразным для больных «угнетённых и подавленных», страдающих «меланхолией» (то есть тем, что позднее стали называть эндогенной меланхолической депрессией), наряду с развлечением их, попытками пробудить их интерес к окружающему, вовлечь в трудовые процессы, и наряду с попытками морально-психологической поддержки и своеобразной психотерапии (которую он называл «моральной терапией») одновременное широкое дополнительное применение пряных и ароматических растений в пище и напитках (настоях или отварах), а также и отдельно в капсулах, с целью стимулировать аппетит и активность больного [Healy D., 2004].

Самое интересное, что методика Ф. Пинеля, уступая, конечно, в эффективности современным методам психотерапии и биологической терапии психических заболеваний, тем не менее, судя по сохранившимся литературным описаниям её эффекта, работала. А дозированное применение различных видов пряных и ароматических растений в лечении «меланхолии» 
было достаточно важной частью терапевтического арсенала Ф. Пинеля и его учеников [Healy D., 2004].

В наше время, в связи с появлением современных методов экстракции активных компонентов растений, а также методов раздельного изучения их нейрохимического и клинико-поведенческого профиля действия, интерес к пряным и ароматическим растениям и к их психотропным и нейротропным свойствам, и к возможностям терапевтического применения их экстрактов или активных веществ в психиатрии и неврологии, проснулся вновь.

Как мы уже говорили, теория, изначально стоявшая за первыми попытками эмпирического применения пряных и ароматических растений в психиатрии и неврологии, вовсе не была научной. Она основывалась на априорном допущении, что если растение имеет яркий пряный вкус и/или запах, то оно должно быть и терапевтически активным. Тем не менее выяснилось, что эта идея была вовсе не такой уж глупой. Сегодня оказалось, что многие пряные и ароматические растения действительно содержат биологически активные вещества, которые могут быть полезны в психиатрии и неврологии. Многие из этих веществ обладают рядом интересных для психиатрии и неврологии психотропных и нейротропных свойств, например, антидепрессивным, противотревожным, психостимулирующим или наоборот успокаивающим (седативным), центральным противорвотным, нейропротективным, антиоксидантным, противовоспалительным, иммуномодулирующим действием и др.

Интересно, что многие из биологически активных веществ пряных и ароматических растений, обладающих психотропными и нейротропными свойствами, оказались по совместительству основными или дополнительными ароматически-вкусовыми веществами этих растений. Таким образом, эмпирические догадки людей Древнего Мира и Средневековья о возможной терапевтической пользе пряных и ароматических растений в психиатрии и неврологии частично подтвердились современной наукой.

В настоящей статье мы подробно рассмотрим имеющуюся доказательную базу относительно возможных психотропных и нейротропных эффектов отдельных компонентов и экстрактов из различных пряных и ароматических растений.

Поскольку пряных и ароматических растений известно очень много, то мы решили остановиться лишь на наиболее известных российскому читателю и потребителю, и присутствующих на рынке России, а также на тех, которые имеют наиболее внушительную доказательную базу по 
применению их компонентов или экстрактов в психиатрии и неврологии. При этом, для исключения возможных разночтений и недопониманий, мы, наряду с традиционными названиями пряностей, приводим также латинские ботанические названия соответствующих им пряных и ароматических растений.

\title{
Доказательная база для применения \\ в психиатрии и неврологии экстрактов и веществ из отдельных пряных и ароматических растений
}

\begin{abstract}
Шафран
Шафраном в кулинарии называют высушенные рыльца цветков шафрана настоящего, или шафрана посевного (Crocus sativus). Шафран в качестве основных ароматически-вкусовых компонентов содержит кроцин, пикрокроцин, диметилкроцин и сафранал. Исторически шафран рекомендовался в традиционной народной медицине в качестве успокаивающего, противотревожного, снотворного, лёгкого антидепрессивного и улучшающего умственную деятельность средства [Hosseinzadeh H., Noraei N.B., 2009]. При этом в эксперименте на мышах доказано, что водный настой шафрана, а также извлечённый из него сафранал действительно обладают противотревожной и снотворно-седативной активностью и способны усиливать снотворное действие барбитуратов и противотревожное действие бензодиазепинов, не усиливая при этом миорелаксацию и атаксию [Hosseinzadeh H., Noraei N.B., 2009].

Шафран также издавна рекомендовали женщинам при жалобах на нерегулярные, болезненные месячные или на синдром предменструального напряжения (ПМС). Современные исследования как на животных, так и на женщинах-добровольцах показывают, что шафран или сафранал, как при вдыхании (в рамках ароматерапии), так и при приёме внутрь, понижает секрецию кортизола и увеличивает секрецию эстрогенов, уменьшая, одновременно, продукцию простагландинов в слизистой матки, что может объяснять его положительное действие при ПМС [Fukui H. et al, 2011].

Кроцин и сафранал также обладают мощной антиоксидантной, противовоспалительной, антиатеросклеротической, антидиабетической активностью как в эксперименте на животных, так и в клинике [Christodoulou E. et al, 2015]. Помимо этого, они обладают многими интересными рецепторными свойствами, в частности способностью блокировать моноаминоксидазы А и В [De Monte C. et al, 2014], активностью в отношении NMDA- и
\end{abstract}


$\sigma_{1}$ рецепторов [Lechtenberg M. et al, 2008]. Показано также, что кроцетин, диметилкроцетин и сафранал являются достаточно сильными ингибиторами ацетилхолинэстеразы с IC50 96,33, 107,1 и 21,09 нМ, соответственно, что может объяснять их эффективность при болезни Альцгеймера и других деменциях, где шафран исторически применялся [Geromichalos G.D. et al, 2012]. Клинически вся эта совокупность рецепторных свойств транслируется в выраженное антидепрессивное, анксиолитическое, прокогнитивное (антидементное) и противосудорожное действие алкалоидов шафрана [Khazdair M.R. et al, 2015].

\section{Ваниль}

Природная ваниль - это продукт, получаемый из плодов (стручковых бобов) некоторых видов орхидей, прежде всего мексиканской Vanilla planifolia. Она и по сей день является второй по дороговизне, после шафрана, пряностью в кулинарии. Её основным ароматически-вкусовым веществом является ванилин. Мексиканские индейцы - ацтеки - издавна использовали ваниль для ароматизации какао и шоколада, а также напитка из листьев коки (послужившего в своё время прототипом Кока-Колы) и, в меньших количествах, для ароматизации мясных блюд (например, блюда, которое позже испанские завоеватели назвали «чили кон карне»). При этом они приписывали ванили, наряду с порошком из бобов какао и листьями коки, психостимулирующие и энергизирующие свойства.

Сегодня, в связи с дороговизной природной ванили и трудоёмкостью её получения, большая часть применяемого в кулинарии и пищевой промышленности ванилина имеет синтетическое происхождение и производится в основном из гваякола либо, реже, из лигнина.

Исследования показывают, что ванилин, как при вдыхании его аромата, так и при его применении внутрь, обладает антидепрессивной и противотревожной активностью в таких экспериментальных моделях депрессии на животных, как хронический непредсказуемый стресс или удаление обонятельной луковицы (ольфакторная бульбэктомия). Применение ванилина приводит к повышению концентраций серотонина, норадреналина и дофамина в мозгу экспериментальных депрессивных животных, к снижению концентрации стрессового гормона кортикостерона в их крови, к нормализации их поведения и исчезновению симптомов депрессии и тревоги. Антидепрессивная и противотревожная активность ванилина в экспериментах на мышах и крысах оказалась сопоставимой с активностью такого эталонного антидепрессанта, как флуоксетин, хотя и ниже активности 
имипрамина. Что особенно важно, сочетанное применение флуоксетина и ванилина привело к повышению эффективности (уменьшению времени иммобилизации животных в модели выученной беспомощности) по сравнению с монотерапией любым из них [Shoeb A. et al, 2013; Xu J et al, 2015].

Изучение механизмов антидепрессивного и противотревожного действия экстракта ванили показало, что ванилин и изоэвгенол, также содержащийся в природной ванили, являются слабыми ингибиторами моноаминооксидазы (MAO) обоих типов и повышают содержание моноаминов в ЦНС [Waye A et al, 2014]. Кроме того, ванилин и изоэвгенол также ингибируют ГАМК-трансаминазу и обладают способностью повышать содержание ГАМК в мозгу, и слабо связываются с бензодиазепиновым сайтом ГАМК-рецептора. Это может объяснять их противотревожную активность [Waye A et al, 2014].

Природная ваниль также содержит ванилолол, являющийся слабым антагонистом $\beta_{1}$ адренергических рецепторов, и потому способный снижать артериальное давление, уменьшать тахикардию и тревожность [BinNan W. et al, 1994].

Ванилин, являясь сильным селективным агонистом ваниллоидных TRPV1 рецепторов, также обладает мощными антиоксидантными, нейропротективными, прокогнитивными и антидементными свойствами. В экспериментальной модели болезни Хантингтона у животных он тормозит прогрессирование нейродегенеративных изменений, поведенческих и двигательных нарушений, нарушений памяти и нарастание симптомов депрессии, причём эффективность его в этой модели сопоставима с эффективностью агомелатина (Вальдоксана) и тетрабеназина. А сочетанное его применение с ними повышает эффективность терапии [Gupta S., Sharma B., 2014 (a)].

Аналогичную, притом сопоставимую с донепезилом и мемантином, нейропротективную и прокогнитивную активность ванилин и другой ароматический компонент природной ванили (4-гидроксибензиловый спирт) проявляют также в экспериментальной модели болезни Альцгеймера на животных [Jayant S. et al, 2016]. В экспериментальной модели сосудистой деменции, вызванной перевязкой обеих сонных артерий у мышей, ванилин уменьшает окислительный стресс, повреждение нейронов и глиальных клеток, реактивное воспаление в зоне ишемии, вызванные ишемией мозга нарушения памяти, поведения и двигательных функций животных, повышает содержание ацетилхолина в их мозгу [Gupta Sю et al, 2014 (b)]. Эффективность ванилина в этой модели оказалась сопоставима с эффек- 
тивностью таких нейропротективных агентов, как атомоксетин и мемантин, причём совместное применение увеличивало эффект [Gupta S. et al, 2014 (b)]. А в экспериментальной модели вызванной скополамином амнезии ванилин не только уменьшает когнитивные нарушения и нарушения памяти, но и стимулирует нейрогенез и дифференцировку нервных клеток в гиппокампе и в области поясной извилины [Kim Y.H., Park J.H., 2017].

Предполагается, что давно известная антидепрессивная активность горького чёрного шоколада у человека может быть частично обусловлена, наряду с другими обнаруженными в чёрном шоколаде антидепрессивными факторами, такими, как анандамид, кофеин, теобромин, фенилэтиламин, омега-3 жирные кислоты, магний, железо, цинк, медь, литий, L-триптофан, различные полифенолы какао, в некоторой степени также содержанием в нём природной ванили или синтетического ванилина [Silva N.R., 2010].

\section{Куркума}

Куркумой в кулинарии называют высушенные и измельчённые в яркий оранжево-жёлтый порошок корневища растения Куркума длинная (Curcuma longa). Они содержат различные так называемые куркуминоиды, в частности куркумин (дифероилметан), деметоксикуркумин и бисдеметоксикуркумин. Содержание куркумина в сухом порошке куркумы в среднем около 3 \% и колеблется в зависимости от сорта растения и условий выращивания. Кроме того, эфирное масло куркумы содержит также турмерон, атлантон, зингиберен и другие летучие соединения.

Куркума и её основной компонент, куркумин, являются мощными антиоксидантами. В этом качестве они привлекли наибольшее среди всех пряных растений (по количеству публикаций) внимание исследователей, в частности, работающих в области лечения и профилактики ревматических и аутоиммунных заболеваний, злокачественных опухолей, сердечно-сосудистых заболеваний, «болезней старения», таких, как сахарный диабет 2-го типа и ожирение [Kocaadam B., Şanlier N., 2017]. Не прошли мимо куркумы и куркумина также и исследователи, изучающие новые возможности лечения психических и неврологических заболеваний, прежде всего депрессий и тревожных состояний, нейродегенеративных заболеваний, дементных состояний [Kocaadam B., Şanlier N., 2017].

На данный момент существует значительное количество РКИ, подтверждающих эффективность и безопасность, хорошую переносимость куркумина в лечении депрессивных и тревожных состояний, когнитивных нарушений, обсессивно-компульсивного расстройства (ОКР), а также та- 
ких психосоматических расстройств, как синдром раздражённого кишечника (СРК) [Ng Q.X. et al, 2017; Lopresti A.L., 2017(a)].

В большинстве случаев, РКИ, посвящённые исследованию эффективности куркумина при психических и неврологических патологиях, относительно невелики по размерам выборки, или отслеживают лишь краткосрочные (до 8-12 недель) эффекты куркумина. Поэтому авторы ряда последних систематических обзоров и мета-анализов призывают к изучению эффективности куркумина, как весьма перспективного терапевтического агента, в более масштабных и более долгосрочных PКИ [Ng Q.X. et al, 2017; Lopresti A.L., 2017(a)].

Одновременно рядом авторов указывается, что, несмотря на эти недостатки, куркумин из куркумы, наряду с сафраналом из шафрана и гиперицином из зверобоя, на сегодняшний день принадлежит к числу наиболее исследованных и имеющих наиболее убедительную среди всех потенциальных растительных антидепрессантов и анксиолитиков доказательную базу для клинического применения [Ng Q.X. et al, 2017; Lopresti A.L., 2017].

Интересно отметить, что в некоторых РКИ показано, что антидепрессивное и противотревожное действие куркумина усиливается при его сочетании с сафраналом из шафрана [Lopresti A.L., Drummond P.D., 2017], с пиперином из чёрного перца [Bhutani M.K. et al, 2009].

\section{Чёрный перец и длинный перец}

Чёрным перцем в кулинарии называют высушенные плоды (ягоды) растения Piper nigrum. Чёрный перец в качестве основного пахуче-вкусового компонента содержит пиперин. Пиперин и его производные обладают рядом интересных свойств, в том числе антидепрессивной, противотревожной и прокогнитивной активностью [Chavarria D. et al, 2016]. Схожий, но не идентичный аромат и вкус имеют также высушенные ягоды так называемого «длинного перца» (растения Piper longum), применяемого как отдельная пряность, в дополнение к чёрному перцу, в индийской и китайской кухнях и в ряде других кухонь народов Азии. Показано, что длинный перец, наряду с пиперином, содержит также особое, отсутствующее в чёрном перце, ароматическое соединение - пиперлонгумин.

В народной медицине Индии, Китая и Малайзии чёрному и длинному перцам традиционно приписывалась противовоспалительная, противоартритная, тонизирующая и общеукрепляющая активность, способность повышать аппетит, улучшать пищеварение, а также антидепрессивные и противотревожные свойства. 
Показано, что экстракт чёрного перца и пиперин повышают биодоступность, антидепрессивную, прокогнитивную и анксиолитическую эффективность куркумина [Jangra A. et al, 2016], ресвератрола (антиоксиданта, содержащегося в красном вине и винограде) [Xu Y. et al, 2016], компонентов родиолы розовой [Panossian A et al, 2008], китайского женьшеня [Li G. et al, 2015(a)].

Показано также, что антидепрессивное, прокогнитивное и противотревожное действие пиперина и экстракта чёрного перца обусловлено его взаимодействием со всеми тремя основными моноаминергическими системами мозга (серотонинергической, норадренергической и дофаминергической) [Li G. et al, 2015(a); Jangra A. et al, 2016;Xu Y. et al, 2016], а также его антиоксидантными свойствами и способностью повышать концентрацию BDNF в мозгу, снижать концентрацию глюкокортикоидов в крови и их вредное воздействие на ЦНС [Maо Q.Q. et al, 2014].

В систематическом обзоре от 2015 года, посвящённом возможностям фитотерапии депрессивных и тревожных состояний на текущий момент, а также возможностям создания в будущем новых антидепрессантов и анксиолитиков на основе компонентов, выделенных из растений, указывается, что пиперин из чёрного перца, наряду с нарингенином из цитрусовых, ресвератролом из красного винограда, куркумином из куркумы, гиперицином и гиперфорином из зверобоя, берберином из барбариса, эвгенолом из гвоздики и некоторыми другими соединениями, является одним из самых перспективных в этом отношении [Bahramsoltani R. et al. 2015].

Пиперлонгумин, выделенный из длинного перца, проявляет антистрессовые, противотревожные, антидепрессивные и анальгетические свойства в экспериментах на животных [Yadav V. et al, 2016]. Кроме того, он также обладает сильной противовоспалительной, антиоксидантной, нейропротективной и прокогнитивной активностью, уменьшает когнитивные нарушения и повреждение мозга, вызванное нейротоксином ротеноном [Wang H. et al, 2016].

\section{Кумин (зира)}

Кумином, или зирой, в кулинарии называют высушенные семена растения Зира (Cuminum ситіпит), применяемые как целиком, так и в измельчённом виде. Его главными ароматическими компонентами являются куминальдегид, кумен и различные терпеноиды.

Кумин (зира) традиционно используется на Востоке не только как пряность, но и как лекарственное растение. В частности, кумину в народной 
медицине многих азиатских стран приписываются, среди прочих, антидепрессивные, тонизирующие, психоэнергизирующие и одновременно антистрессовые, противотревожные свойства и способность улучшать память и когнитивные функции.

Исследования на животных показывают, что порошок, экстракт и эфирное масло кумина действительно способны уменьшать когнитивные нарушения и нарушения памяти, вызываемые, например, введением экспериментальным животным скополамина, а также оказывать противотревожное и антистрессовое воздействие на поведение животных, снижать уровень перекисного окисления липидов и другие маркеры окислительного стресса в их крови, понижать уровень стрессового гормона кортикостерона в их крови и моче [Koppula S., Choi D.K., 2011].

В обзоре польских авторов указывается, что порошок, экстракт и эфирное масло кумина обладают антидепрессивными свойствами как в экспериментальных моделях депрессии на животных, так и в опубликованных на сегодня пилотных открытых исследованиях на людях, и что экстракт кумина усиливает антидепрессивное действие таких известных растительных антидепрессантов, как экстракт зверобоя продырявленного, экстракт родиолы розовой, экстракт женьшеня, сафранал из шафрана. Они призвали к дальнейшему исследованию возможностей фитотерапии депрессий, в том числе комбинированной, в формате РКИ [Muszyńska B. et al, 2015].

\section{Чёрный тмин (чернуика, нигелла)}

Чёрным тмином, или чернушкой, чёрным кумином, римским кориандром, нигеллой, в кулинарии называют высушенные семена растения Чернушка посевная (Nigella sativa). Оно широко возделывается по всему миру и используется как пряность.

Эфирное масло чёрного тмина содержит тимохинон, нигелон (дитимохинон), мелантин, нигеллин, а также транс-анетол (тот же ароматический компонент, что и в анисе).

Семенам чёрного тмина в традиционной народной медицине приписывают наличие множества разнообразных лекарственных свойств, в частности мочегонных, ветрогонных, желчегонных, слабительных, противоглистных, противопростудных, а также способность повышать секрецию молока у кормящих женщин.Внимание исследователей, занимающихся поиском новых антидепрессантов и анксиолитиков, привлекло то, что среди прочего, чёрному тмину народная медицина многих стран приписывает также наличие 
антидепрессивных, противотревожных, успокаивающих свойств и способности улучшать память и когнитивные функции.

На животных показано, что порошок, экстракт и эфирное масло чёрного тмина действительно оказывают антидепрессивное и противотревожное действие в ряде экспериментальных моделей депрессии и тревоги. Более того, авторам удалось показать, что этот эффект чёрного тмина обусловлен в основном взаимодействием с серотонинергическими системами мозга. Применение чёрного тмина приводит к повышению концентрации серотонина в ЦНС, концентраций L-триптофана в ЦНС и крови экспериментальных животных, и к замедлению катаболизма L-триптофана и серотонина [Perveen T. et al, 2009].

В других экспериментах было показано, что порошок, экстракт и эфирное масло чёрного тмина, а также выделенный из него тимохинон, оказывают антиоксидантное и нейропротективное действие и улучшают когнитивные и двигательные функции животных, уменьшают степень повреждения мозга в экспериментальных моделях ишемического инсульта [Azzubaidi M.S. et al, 2012] и эпилептического статуса [Shao Y. et al, 2017].

\section{Анис и бадьян (звёздчатый анис)}

Анисом в кулинарии называют плоды растения Анис настоящий, он же Бедренец анисовый (Pimpinella anisum). Основными ароматически-вкусовыми веществами эфирного масла аниса являются изомеры анетола цис-анетол и транс-анетол. В нём присутствуют в меньших количествах также метилхавикол, эстрагол, анисовый спирт, анисовый альдегид, анисовый кетон, анисовая кислота и др.

Плоды аниса и извлечённое из них эфирное масло обладают множеством фармакологических свойств, в частности, отхаркивающими, ветрогонными, желчегонными, спазмолитическими, слабительными, противовоспалительными и местноанестезирующими. В народной медицине плодам аниса приписывается также способность повышать секрецию молока у кормящих женщин.

Относительно недавно у порошка аниса или эфирного масла аниса были документально подтверждены на человеке издавна приписывавшиеся ему в народной медицине антидепрессивные, противотревожные и успокаивающие свойства. В частности, в одном недавнем (2017 года) РКИ показана антидепрессивная и противотревожная активность эфирного масла аниса внутрь при лёгких и средних депрессиях у больных с 
синдромом раздражённого кишечника (СРК). Она оказалась статистически достоверно выше плацебо и сопоставима с эффективностью эталонного антидепрессанта эсциталопрама у этих больных [Mosaffa-Jahromi M. et al, 2017]. В других двух РКИ от 2015 года было показано, что порошок аниса эффективнее плацебо и сопоставим с эсциталопрамом по антидепрессивной и противотревожной активности при лёгких и средних послеродовых депрессиях у женщин, а также при лёгких и средних депрессиях у больных, страдающих функциональной диспепсией [Ghoshegir S.A. et al, 2015].

Антидепрессивная и противотревожная активность плодов аниса или эфирного масла аниса подтверждается также и в экспериментах на животных [Gamberini M.T. et al, 2015; Shahamat Z. et al, 2016].

В одной из экспериментальных моделей болезни Альцгеймера у животных - в модели вызванной скополамином амнезии - было также показано, что эфирное масло аниса не только уменьшает проявления депрессии и тревоги у этих животных, но и улучшает их память и способность ориентироваться в пространстве [Aydin E. et al, 2016].

Отчасти сходное с анисом настоящим по химическому составу эфирного масла, но ботанически не родственное растение Illicium verum (звёздчатый анис, или бадьян) также обладает антидепрессивными и противотревожными свойствами и в клинике, и в экспериментах на животных. Более того, в одном из исследований авторам удалось показать, что антидепрессивные и противотревожные свойства эфирных масел бадьяна и аниса обусловлены в основном содержанием в них транс-анетола [Miyagawa M. et al, 2014].

Кроме антидепрессивных, противотревожных и прокогнитивных свойств, у плодов аниса также обнаружены нейропротективные, противосудорожные, обезболивающие (анальгетические), мышечно-расслабляющие, антиоксидантные свойства [Pourgholami M.H. et al, 1999; Karimzadeh F. et al, 2012; Shojaii A., Abdollahi Fard M., 2012; Abdollahi Fard M., Shojaii A., 2013].

У больных с сахарным диабетом плоды аниса способствуют снижению уровня глюкозы в крови, нормализации липидного спектра и уровня холестерина, снижению уровня перекисного окисления липидов. Эфирное масло или плоды аниса способны смягчать проявления опиоидной абстиненции, уменьшать выраженность симптомов климакса (в частности, «приливы»), предменструального дисфорического синдрома, дисменореи [Shojaii A., Abdollahi Fard M., 2012]. 


\section{Корица и кассия}

Корицей в кулинарии называют высушенную кору коричного дерева, или растения Коричник цейлонский (Cinnamoтuт verum). В кулинарии применяют (и часто тоже называют корицей) также более дешёвую кассию - высушенную кору китайского коричного дерева (Cinnaтотит aromaticum).

Эфирное масло обоих видов коричного дерева содержит в качестве одного из главных ароматически-вкусовых компонентов коричный альдегид (циннамальдегид, или циннамаль, до 90\% содержания в эфирном масле), коричный спирт и коричную кислоту. Кроме того, оно также содержит эвгенол, $\beta$-кариофиллен, линалоол, фелландрен, метилхавикол.

Показано, что циннамальдегид (как уже упоминалось, основной ароматически-вкусовой компонент корицы и кассии) - является агонистом TRPA1 ваниллоидных рецепторов, и что он обладает антидепрессивными и противотревожными свойствами как в клинике, так и в экспериментах на животных, как внутрь, так и в виде ароматерапии [Ito N. et al, 2011; de Moura J.C. et al, 2014]. Циннамальдегид также усиливает антидепрессивное действие периллового альдегида, основного активного компонента плодов Perilla frutescens, входящих в состав традиционной смеси «кампо», применяемой в японской и китайской медицине для лечения депрессий [Ito N. et al, 2011].

В другом исследовании было показано, что циннамальдегид является мощным ингибитором циклооксигеназы типа 2 (ЦОГ-2), и, оказывая сильное противовоспалительное действие в ЦНС, способен проявлять сопоставимое с целекоксибом антидепрессивное действие в экспериментальных моделях депрессии, в том числе у пожилых животных [Yao Y. et al, 2015].

Циннамальдегид (коричный альдегид), коричный спирт и коричная кислота обнаруживаются в значительных количествах также в экстрактах из другого известного адаптогенного и антидепрессивного растения родиола розовая (Rhodiola rosea). Оказалось, что циннамальдегид усиливает антидепрессивное и антистрессовое действие других активных компонентов родиолы розовой, таких, как родиолозид, розавин, розарин, розин. Более того, обнаружилось, что сочетание экстракта родиолы розовой и экстракта чёрного перца, содержащего пиперин, приводит к усилению антидепрессивного и стимулирующего эффекта родиолы розовой и к замедлению элиминации её активных компонентов из организма [Panossian A. et al, 2008]. Как тут не вспомнить о том, что в кухнях народов Ближнего Востока и Юго-Восточной Азии корица и чёрный перец часто сочетаются, и, видимо, неспроста [Panossian A. et al, 2008]. 
Кроме того, показано также, что порошок и экстракт (эфирное масло) корицы или кассии, а также очищенный циннамальдегид, повышают инсулин-чувствительность периферических тканей и ЦНС, тормозят развитие сахарного диабета 2-го типа и ожирения в экспериментальной модели чрезмерно высококалорийного питания, улучшают память, настроение, поведение и когнитивные функции и тормозят развитие Альцгеймер-подобных изменений в ЦНС у экспериментальных животных с диабетом 2-го типа [Anderson R.A. et al, 2013; Jawale A. et al, 2016]. В другой экспериментальной модели болезни Альцгеймера, вызванной стрептозотоцином, циннамальдегид или экстракт коры коричного дерева также проявляет нейропротективные, антидепрессивные, противотревожные и прокогнитивные свойства [Malik J. et al, 2015].

В экспериментальной модели депрессии, вызванной инъекцией мышам бактериальных липополисахаридов, показано, что циннамальдегид и экстракт корицы или кассии оказывают антиоксидантное и противовоспалительное действие в ЦНС, уменьшают воспалительную активацию нейроглии, секрецию воспалительных цитокинов, снижают активацию синтазы оксида азота (II) и образование оксида азота (II), ослабляют окислительный и нитрозативный стресс и свободнорадикальное повреждение нейронов, предотвращают их гибель от апоптоза [Zhang L. et al, 2016(b)]. Это транслируется в их антидепрессивное и прокогнитивное действие, улучшение памяти и поведения экспериментальных животных в данной модели [Zhang L. et al, 2016(b)].

\section{Кориандр и кинза}

Кориандром в кулинарии называют семена растения Кориандр посевной или, иначе, Кориандр овощной (Coriandrum sativum). Зелень этого же растения называют в кулинарии кинзой.

Плоды (семена) и зелень кориандра (кинза) содержат стероидное соединение кориандрол, алкалоид кориандрин, различные стерины, каротиноиды, рутин и другие полифенолы, аскорбиновую кислоту, различные органические кислоты, дубильные вещества, а также летучее эфирное масло. Главными компонентами эфирного масла кориандра являются линалоол (до 60-80\% содержания) и гераниол (до 5\%).

Кориандр обладает множеством фармакологических свойств, в частности, антибактериальными, противогрибковыми, антиоксидантными, антигельминтными. Он стимулирует аппетит, повышает секрецию пищеварительных соков (желудочного, панкреатического, кишечного) и желчи, 
обладает желчегонными, спазмолитическими, ветрогонными и лёгкими слабительными свойствами, имеет отхаркивающее действие.

В народной медицине кориандру традиционно приписывается, среди прочего, также наличие успокаивающих (седативных), противотревожных, снотворных и обезболивающих (анальгетических) свойств.

Эксперименты на животных показывают, что молотый кориандр, экстракт из него и его эфирное масло, а также его основной компонент линалоол, действительно обладают седативными, противотревожными и снотворными свойствами, причём они проявляются на таких разных животных, как лабораторные мыши, крысы, морские свинки и даже куры [Gastón M.S. et al, 2016]. Анальгетическая активность кориандра и его эфирного масла также подтвердилась в эксперименте, причём было показано, что она опосредуется активацией эндогенной опиоидной системы и снимается или предотвращается налоксоном [Taherian A.A. et al, 2012].

Кроме того, у кориандра и его эфирного масла также показана противосудорожная, противовоспалительная, иммуномодулирующая и антиоксидантная активность, способность снижать содержание холестерина и улучшать липидный профиль крови, повышать чувствительность тканей к инсулину и снижать уровень глюкозы в крови, тормозить развитие экспериментального сахарного диабета (СД) 2-го типа, ожирения и метаболического синдрома [Laribi B. et al, 2015]. А это весьма важно в контексте психиатрии, в свете высокой коморбидности СД 2-го типа, ожирения и метаболического синдрома с психическими заболеваниями.

В одном интересном небольшом РКИ, вовлёкшем 68 пациентов с хронической мигренью, было показано, что сироп кориандра и эфирное масло кориандра обладают противомигренозными свойствами и способны уменьшать продолжительность и частоту мигренозных приступов и среднюю степень выраженности болевого синдрома на фоне мигренозного приступа, и потенцируют противомигренозное действие вальпроатов, а также улучшают настроение и самочувствие больных мигренью, способствуют редукции коморбидных с мигренью депрессивных и тревожных расстройств и расстройств сна [Kasmaei H.D. et al, 2016].

Экстракт и эфирное масло кориандра также обладают нейропротективными свойствами, уменьшают окислительный стресс и свободнорадикальное повреждение нейронов, вызванное экспериментальными эпилептическими судорогами [Pourzaki M. et al, 2017], уменьшают воспалительную активацию нейроглии, реактивный глиоз и тормозят прогрессирование когнитивных и поведенческих нарушений в экспериментальной 
модели болезни Альцгеймера [Liu Q.F. et al, 2016], улучшают память и обучаемость как у человека, так и у экспериментальных животных, снижают вызванные ЭСТ или воздействием диазепама, скополамина нарушения памяти [Zargar-Nattaj S.S. et al, 2011].

Кориандр и его экстракт также эффективны в экспериментальной модели орофациальных поздних дискинезий, вызванных длительным лечением животных антихолинэстеразным средством такрином или антипсихотиком галоперидолом [Mohan M. et al, 2015].

\section{Кардамон}

Кардамоном в кулинарии называют семена растения Elettaria cardaтотит, родиной которого являются Индия, Бутан, Индонезия и Непал. Кардамон и по сей день является третьей по дороговизне пряностью после шафрана и природной ванили. Эфирное масло кардамона содержита-терпинеол и $\alpha$-терпинилацетат (45\%), $\beta$-мирцен (27\%), лимонен ( $8 \%)$, ментон $(6 \%), \beta$-фелландрен $(3 \%), 1,8$-цинеол $(2 \%)$, сабинен $(2 \%)$ и гептан $(2 \%)$, а также борнеол.

В традиционной восточной медицине кардамону приписывается наличие одновременно стимулирующих, энергизирующих, тонизирующих, антидепрессивных и противотревожных, успокаивающих свойств, а также свойств афродизиака (средства, повышающего либидо и половую потенцию у мужчин). В качестве тоника и энергетика кардамон часто добавляется в кофе, чай (так называемый бедуинский чай и чай масала). Кроме того, он обладает также бактерицидными, противогрибковыми, отхаркивающими и ветрогонными свойствами, стимулирует желудочную секрецию.

В эксперименте кардамон проявляет антидепрессивную и противотревожную активность, в частности, в модели хронического стресса и в модели посттравматического стрессового расстройства у животных [Masoumi-Ardakani Y. et al, 2017]. Кроме того, ряд компонентов кардамона также являются сильными ингибиторами $\beta$-секретазы и тормозят развитие экспериментальной болезни Альцгеймера, снижают накопление $\beta$-амилоида в ЦНС, реактивное воспаление, окислительный стресс и гибель нейронов [Matsumura S. et al, 2016].

Кардамон также обладает нейропротективными, противовоспалительными антиоксидантными, противосудорожными и анальгетическими свойствами. В экспериментах на животных он уменьшает когнитивные нарушения, вызванные электросудорожной терапией (ЭСТ) или коразоловыми судорогами, и повреждение нейронов, вызываемое преходящей ише- 
мией мозга или воспалительными цитокинами (введением бактериального липополисахарида) [Masoumi-Ardakani Y. et al, 2016].

В нескольких РКИ показана способность кардамона улучшать чувствительность тканей к инсулину, снижать уровень глюкозы и холестерина в крови, нормализовывать липидный спектр крови и маркеры окислительного стресса и воспаления у больных с ожирением, сахарным диабетом или преддиабетом, гиперлипидемией (то есть оказывать противодиабетическое и гиполипидемическое, гипохолестеринемическое действие), способствовать похудению [Kazemi S. et al, 2017]. Что особенно важно, это действие кардамона сопровождалось улучшением настроения и общего самочувствия больных, улучшением их когнитивного функционирования, снижением уровней коморбидной депрессии и тревоги [Kazemi S. et al, 2017].

\section{Розмарин}

Розмарином в кулинарии называют листья, цветки или молодые побеги растения Розмарин лекарственный, или Розмарин обыкновенный (Rosmarinus officinalis). Он обладает сильным пряным, сладковатым, камфорным ароматом, напоминающим аромат сосновой хвои, и очень пряным, острым, даже горьковатым или жгучим при передозировке вкусом.

Розмарин употребляется в кулинарии для ароматизации блюд из рыбы, овощных супов и блюд, бульонов, салатов, маринадов, мясного фарша, грибов, жареного или запечённого мяса, птицы, дичи, грибов, картофеля, мягких сыров и сдобного теста. Он является традиционной пряностью средиземноморской и ближневосточной кухонь.

В составе листьев и цветков розмарина обнаружены алкалоид розмарицин, урсоловая и розмариновая кислоты, а также такие соединения, как сальвигенин, розманол, цирсимаритин. Эфирное масло розмарина содержит $\alpha$-пинен (30\%), камфен (20\%), цинеол (10\%), борнеол, L-камфору, кариофиллен, борнилацетат, лимонен, а также различные смолы и горечи.

Розмарин лекарственный обладает множеством фармакологических свойств. В частности, он повышает секрецию пищеварительных соков (желудочного, панкреатического, кишечного) и желчи, оказывает желчегонное и спазмолитическое действие, способствует улучшению пищеварения, обладает бактерицидными и противогрибковыми свойствами благодаря содержанию сильных фитонцидов, имеет сильные антиоксидантные свойства как ex vivo (например, предотвращает прогоркание масла), так и в организме. Он также увеличивает силу сердечных сокращений, стимулирует 
дыхание, слегка повышает артериальное давление (в основном, вероятно, за счёт действия камфоры).

Показано, что розмарин обладает одновременно и лёгкими тонизирующими, психостимулирующими, и лёгкими седативными свойствами, уменьшает стресс, нервное напряжение, переутомление, усталость, а также проявления климактерического синдрома и синдрома предменструального напряжения у женщин. Розмарин и ряд выделенных из него соединений, в частности сальвигенин, розманол, цирсимаритин, обладают антидепрессивной, противотревожной и обезболивающей (анальгетической) активностью в экспериментах на животных. Механизм их действия обусловлен модулированием активности ГАМК-А рецепторов [Abdelhalim A. et al, 2015].

A-пинен, основной (до 30 \% содержания) ароматический компонент эфирного масла розмарина, оказывает противовоспалительное действие, в том числе в ЦНС, снижает воспалительную активацию нейроглии, выделение таких воспалительных цитокинов, как фактор некроза опухолей- $\alpha$ (ФНО- $\alpha)$, интерлейкины 1 и 6 (ИЛ-1, ИЛ-6), ингибирует синтазу оксида азота (II) и уменьшает образование оксида азота (NO), окислительный и нитрозативный стресс нейронов, ингибирует циклооксигеназу типа 2 (ЦОГ-2) и снижает образование простагландинов в экспериментальной модели депрессии у мышей, вызванной введением бактериального липополисахарида [Kim D.S. et al, 2015]. Это транслируется в его противотревожную, антидепрессивную и прокогнитивную активность в данной модели, в улучшение поведения и когнитивных функций экспериментальных животных [Kim D.S. et al, 2015].

Антидепрессивная и противотревожная активность розмарина проявляется и в других экспериментальных моделях депрессии на животных, в частности в моделях хронического непредсказуемого стресса, ольфакторной бульбэктомии (удаления обонятельной луковицы), социальной изоляции животных. При этом она оказалась сопоставима с антидепрессивной и противотревожной активностью флуоксетина. Это придаёт дополнительный вес традиционному использованию розмаринового чая или настоя в народной медицине для лечения депрессивных и тревожных состояний [Machado D.G. et al, 2012]. Показано, что соединения, содержащиеся в розмарине, воздействуют на различные моноаминергические системы мозга - серотониновую, норадреналиновую и дофаминовую, и приводят к повышению концентраций всех трёх моноаминов в ЦНС, и что антидепрессивное действие экстракта розмарина уменьшается или исчезает при введении экспериментальным животным блокаторов соответствую- 
щих моноаминовых рецепторов или блокаторов биосинтеза моноаминов [Machado D.G. et al, 2009].

Ещё один важный компонент розмарина, карнозиновая кислота, является ингибитором матриксной металлопротеиназы 9-го типа (ММП-9), и в этом качестве, подобно миноциклину, оказывает противовоспалительное действие в ЦНС и суставах, тормозит воспалительную активацию нейроглии при депрессиях, воспаление синовиальной ткани при артритах, замедляет развитие атеросклероза сосудов и утолщение их интимы при экспериментальном атеросклерозе [Yu Y.M. et al, 2008].

Розмарин также улучшает память, концентрацию внимания и когнитивные функции как у здоровых добровольцев, так и у пациентов с такими заболеваниями, как болезнь Альцгеймера, физиологическое возрастное когнитивное снижение, последствия ишемического инсульта или черепно-мозговых травм. В экспериментах на животных показано, что розмарин повышает содержание ацетилхолина в ЦНС, уменьшает окислительное повреждение нейронов и реактивный астроцитоз в таких моделях, как экспериментальная болезнь Альцгеймера [Huegel H.M., 2015], экспериментальный ишемический инсульт [Seyedemadi P. et al, 2016], повторные черепно-мозговые травмы [Song H. et al, 2016], физиологическое возрастное когнитивное снижение [Pengelly A. et al, 2012]. Ряд компонентов розмарина, в частности розмариновая кислота, лютеолин-7-О-глюкуронид, кофейная кислота, являются ингибиторами ацетилхолинэстеразы и бутирилхолинэстеразы [Ferlemi A.V. et al, 2015].

Розмарин также способствует улучшению сексуальной функции и коррекции психогенной и нейрогенной импотенции у мужчин, повышению содержания тестостерона в плазме крови мужчин [Basson R., Bronner G., 2015].

\section{Базилик}

Базиликом в кулинарии называют зелень растения Базилик душистый (Ocimum basilicum). В кулинарии некоторых народов используют также другие представители семейства базиликовых, например, «священный тайский базилик», или туласи (Ocimum tenuiflorum или Ocimum sanctum), лимонный базилик (Ocimum citriodorum или Ocimum africanum), американский базилик (Ocimum americanum). Кроме того, у этих видов базилика существует множество сортов или культиваров, например, «анисовый базилик» (или «лакричный базилик»), «сладкий базилик», «африканский голубой базилик», «камфорный базилик», «коричный базилик», с соответствующими вариациями запаха. 
Химический состав эфирного масла базилика очень сложный (один из самых сложных среди всех пряных растений). Кроме того, он сильно варьирует в зависимости не только от вида растения, но и от сорта (культивара) и условий произрастания. В частности, в нём обнаружены эвгенол (придающий запах гвоздики), цитраль (придающий запах мелиссы), лимонен (придающий запах лимона), камфора и камфен, цис-анетол и транс-анетол (придающие запах аниса или лакрицы), а также такие компоненты, как цитронеллол (ароматическое вещество розы, герани и цитронеллы), линалоол (главное ароматическое вещество кориандра), мирцен (главный ароматический компонент лаврового листа и мирсии), $\alpha$-пинен (дающий запах сосновой смоле), $\beta$-оцимен, терпинеол, линалилацетат, фенчилацетат, транс- $\beta$-оцимен, 1,8 -цинеол, метилэвгенол, метилхавикол, $\beta$-кариофиллен, метилциннамат и др.

В традиционной народной медицине многих народов, а также в древней индийской и персидской медицине, базилику приписывалось наличие, среди прочего, также антидепрессивных, противотревожных, успокаивающих и снотворных свойств, способность улучшать память, концентрацию внимания и когнитивные функции.

В исследованиях на животных показано, что водно-спиртовой экстракт и эфирное масло иранской разновидности базилика (содержащее $42,8 \%$ метилхавикола, $13 \%$ гераниала, $12,2 \%$ нерала, и 7,2\% $\beta$-кариофиллена) действительно обладает выраженным противотревожным, успокаивающим и снотворным действием, сопоставимым с таковым у диазепама, а также умеренными антидепрессивными свойствами, сопоставимыми с действием эсциталопрама, но уступающими имипрамину [Rabbani M. et al, 2015]. Кроме того, экстракт и эфирное масло базилика также улучшают память и обучаемость экспериментальных животных, повышают их интерес к окружающей обстановке и исследованиюеё новизны, уменьшают страх перед новым и незнакомым [Zahra K. et al, 2015]. В экспериментальной модели ишемического инсульта на мышах показано, что экстракт и эфирное масло базилика оказывают нейропротективное и антиоксидантное действие, уменьшают ишемическое повреждение мозга мышей, окислительный стресс и гибель нейронов, улучшают когнитивные и двигательные функции животных, перенёсших ишемию мозга [Bora K.S. et al, 2011].

В эфирном масле базилика обнаружены вещества, обладающие антихолинэстеразной активностью и повышающие содержание ацетилхолина в мозгу, а также сильные антиоксиданты. Показано, что эфирное масло и водно-спиртовой экстракт базилика улучшают когнитивные функции и 
тормозят прогрессирование болезни в экспериментальной модели болезни Альцгеймера, а также уменьшают когнитивные нарушения, вызываемые такими М-холинолитиками, как скополамин [Singh V. et al, 2016].

В одном небольшом РКИ на здоровых добровольцах показано, что эфирное масло и экстракт священного тайского базилика действительно обладает традиционно приписывавшимися ему в тайской, тибетской и китайской медицине прокогнитивными, противотревожными и антистрессовыми свойствами, улучшает память, способность к решению интеллектуальных задач, снижает уровень кортизола в крови добровольцев и уровень их тревожности при выполнении задач [Sampath S. et al, 2015].

\section{Сельдерей}

Сельдереем в кулинарии называют корневища, стебли, листья и семена растения Сельдерей пахучий (Apium graveolens). В народной медицине многих европейских стран, включая Россию, этому растению издавна приписывалось наличие ряда полезных для здоровья свойств, в частности, мочегонного, желчегонного, противовоспалительного, общеукрепляющего, улучшающего зрение, пищеварение и сердечно-сосудистую деятельность. А в народной медицине Дании и других стран Центральной Европы ему также традиционно приписывалось наличие антидепрессивных и противотревожных свойств и способности улучшать память и когнитивные функции [Jäger A.K. et al, 2013]. Эти свойства экстракта, сока и эфирного масла сельдерея подтвердились в экспериментах на животных [Jäger A.K. et al, 2013].

Кроме того, было также показано, что экстракт, сок и эфирное масло сельдерея содержат, помимо каротиноидов, биофлавоноидов и других сильных антиоксидантов, также вещества, способные ингибировать моноаминоксидазу типа А (МАО-А), ацетилхолинэстеразу и ГАМК-трансферазу, и повышать содержание моноаминов, ацетилхолина и ГАМК в ЦНС экспериментальных животных [Boonruamkaew P. et al, 2017]. Это может объяснять их антидепрессивное, противотревожное и прокогнитивное действие [Jäger A.K. et al, 2013; Boonruamkaew P. et al, 2017].

В составе экстракта, сока и эфирного масла сельдерея обнаружен в значительных количествах L-3-n-бутилнафталид, проявляющий мощные антиоксидантные, гипотензивные, антиатеросклеротические, гиполипидемические и противодиабетические свойства [Zhang L. et al, 2012]. Это соединение также проявляет нейропротективную и прокогнитивную активность в экспериментальных моделях болезни Альцгеймера [Xiang J. et 
al, 2014], сосудистой деменции [Zhang L. et al, 2012], вызванных диабетом или ожирением когнитивных нарушений [Li J. et al, 2015].

Сельдерей также содержит в значительных количествах фитоэстрогены. Экстракт или сок сельдерея рекомендуется в традиционной народной медицине в качестве средства для облегчения симптомов климакса и менопаузы или синдрома предменструального напряжения [Khalid Z. et al, 2016].

В литературе описан интересный случай женщины с депрессией (которая, как предполагалось до описываемого случая, носила характер униполярной, а не биполярной депрессии), которая достигла стабильной ремиссии на комбинации венлафаксина с экстрактом зверобоя (слабым растительным антидепрессантом, ингибитором МАО-А). Однако после самовольного подключения к терапии экстракта корня сельдерея, по поводу начавшегося климакса и связанных с ним симптомов, эта женщина испытала первый в своей жизни маниакальный эпизод, после чего её диагноз был изменен с рекуррентного депрессивного расстройства (РДР) на биполярное аффективное расстройство (БАР). Авторы связывают описанный случай индукции мании с усилением под влиянием экстракта сельдерея и содержащихся в нём фитоэстрогенов серотонинергической и норадренергической нейропередачи (по аналогии с воздействием на моноаминовые системы эстрадиола), а также с наличием в экстракте сельдерея природных ингибиторов МАО-А, и резким повышением суммарной степени блокады МАО-А на фоне уже имеющегося в схеме экстракта зверобоя [Khalid Z. et al, 2016].

\section{Гвоздика}

Гвоздикой в кулинарии называют высушенные нераспустившиеся бутоны цветков гвоздичного дерева, или растения Сизигиум ароматный (Eugenia aromatica, оно же Syzygium aromaticum). Эфирное масло гвоздики содержит от $72 \%$ до 90 \% эвгенола, в наибольшей степени ответственного за аромат гвоздики. Кроме того, оно содержит также метилсалицилат, ацетилэвгенол, $\beta$-кариофиллен, ванилин, кратеголовую кислоту, ряд танинов, таких, как бикорнин, галлотанновая кислота, флавоноиды эвгенин, кемпферол, рамнетин, эвгенитин, ряд тритерпеноидов, таких, как олеаноловая кислота, стигмастерол, кампестерол, и ряд сесквитерпеновых соединений.

Эфирное масло гвоздики и эвгенол являются сильными антисептиками, антиоксидантами и консервантами, оказывают выраженное бактерицидное и противогрибковое действие, отпугивают насекомых. В этом качестве они по сей день применяются для консервации фармацевтиче- 
ских препаратов (микстур и др.), изготовления бактерицидных раневых повязок, а также в стоматологической практике как местный антисептик в составе полосканий, зубных паст, составов для изготовления временных лечебных пломб и заполнения кариозных полостей и т.д.

Эвгенол, главный компонент эфирного масла гвоздики, достаточно токсичен в чистом виде. Так, доза 5-10 мл эфирного масла гвоздики способна вызвать тяжёлое, близкое к фатальному, отравление у двухлетнего ребёнка.

В традиционной китайской и индийской медицине бутонам гвоздичного дерева приписываются болеутоляющие, спазмолитические, ветрогонные, желчегонные, глистогонные свойства, противовоспалительное и противоревматическое действие. Им также приписывается наличие антидепрессивных, противотревожных, успокаивающих и одновременно тонизирующих, стимулирующих, энергизирующих свойств [Mehta A.K. et al, 2013].

В экспериментах на животных показано, что эфирное масло гвоздики и её водно-спиртовой экстракт действительно обладают антидепрессивной и психостимулирующей (амфетаминоподобной) активностью [Mehta A.K. et al, 2013]. Показано, что в реализации антидепрессивного и психостимулирующего эффектов эфирного масла и экстракта гвоздики участвуют все три основные моноаминергические системы мозга - серотонинергическая, дофаминергическая и норадренергическая. Под их влиянием повышается содержание в ЦНС всех трёх моноаминов. Антидепрессивное и психостимулирующее действие экстракта или эфирного масла гвоздики снижается или предотвращается введением блокаторов соответствующих рецепторов (галоперидола, празозина, кетансерина) [Victoria F.N. et al, 2013].

В другой экспериментальной модели было показано, что эфирное масло и экстракт гвоздики, традиционно входившие в состав смесей, применявшихся в японской медицине «кампо» при лечении тревожных и стрессовых состояний, действительно обладают противотревожными и лёгкими седативными свойствами. При скрининге травяных компонентов, входящих в состав этих смесей, было обнаружено, что эфирное масло и экстракт гвоздики содержат вещества, взаимодействующие с ГАМК-А рецепторами и 5-НТ, серотониновыми рецепторами [Hoffmann K.M. et al, 2016].

Кроме того, также было показано, что эфирное масло и экстракт гвоздики, а также выделенный из неё компонент бифлорин, улучшают когнитивные функции и память животных в экспериментальных моделях болезни Альцгеймера, вызванной скополамином амнезии и др. [Alikatte K.L. et al, 2012; Jeon S.J. et al, 2017]. 
Эфирное масло и водно-спиртовой экстракт гвоздики также обладают сильной антиоксидантной, противовоспалительной и противодиабетической активностью, снижают перекисное окисление липидов, образование свободных радикалов, гликирование белков в экспериментальной модели сахарного диабета, повышают чувствительность периферических тканей и ЦНС к инсулину, уменьшают вызванные сахарным диабетом когнитивные нарушения [Oboh G. et al, 2015].

\section{Дуиистый перец (пимента)}

Душистым перцем, или английским перцем, пиментой, в кулинарии называют высушенные незрелые плоды (ягоды) растения Пимента лекарственная (Pimenta dioica, оно же Pimenta pseudocaryophyllus). Изначально родиной этого растения были Мексика, Ямайка, Карибские острова, Центральная и Южная Америка. В дальнейшем оно широко распространилось и ныне повсеместно возделывается в странах с тёплым и влажным, тропическим или субтропическим климатом, в особенности на Ближнем Востоке.

Эфирное масло пименты чрезвычайно сложно по составу (откуда происходит английское название пименты - allspice, буквально «все специи в одной» - по мысли британцев, аромат пименты сочетает в себе ароматы гвоздики, мускатного ореха и корицы). Одними из основных его компонентов являются эвгенол, изоэвгенол, метилизоэвгенол.

В народной медицине индейцев-ацтеков пименте приписывались, среди прочих, антидепрессивные и противотревожные свойства. Изучение эфирного масла пименты на животных подтвердило наличие у него противотревожной и антидепрессивной активности [Fajemiroye J.O. et al, 2014; 2016].

\section{Сиисок литературы / References}

1. Abdelhalim A. et al. Antidepressant, anxiolytic and antinociceptive activities of constituents from Rosmarinus officinalis //Journal of Pharmacy \& Pharmaceutical Sciences. 2015. V. 18. №. 4, pp. 448-459.

2. Abdollahi Fard M., Shojaii A. Efficacy of Iranian traditional medicine in the treatment of epilepsy //BioMed research international. 2013. V. 2013.

3. Alikatte K.L. et al. Antiamnesic activity of Syzygium cumini against scopolamine induced spatial memory impairments in rats //Brain and Development. 2012. V. 34. №. 10, pp. 844-851.

4. Anderson R.A. et al. Cinnamon counteracts the negative effects of a high fat/ high fructose diet on behavior, brain insulin signaling and Alzheimer-associated changes //PloS one. 2013. V. 8. №. 12. P. e83243. 
5. Aydin E. et al. The effects of inhaled Pimpinella peregrina essential oil on scopolamine-induced memory impairment, anxiety, and depression in laboratory rats //Molecular neurobiology. 2016. V. 53. №. 9, pp. 6557-6567.

6. Bahramsoltani R. et al. Phytochemical constituents as future antidepressants: a comprehensive review //Reviews in the Neurosciences. 2015. V. 26. №. 6, pp. 699-719.

7. Bhutani M.K., Bishnoi M., Kulkarni S.K. Antidepressant like effect of curcumin and its combination with piperine in unpredictable chronic stress-induced behavioral, biochemical and neurochemical changes //Pharmacology Biochemistry and Behavior. 2009. V. 92. №. 1, pp. 39-43.

8. Bin-Nan W. et al. Vaninolol: a new selective $\beta 1$-adrenoceptor antagonist derived from vanillin //Biochemical pharmacology. 1994. V. 48. №. 1, pp. 101-109.

9. Boonruamkaew P. et al. Apium graveolens extract influences mood and cognition in healthy mice //Journal of Natural Medicines. 2017, pp. 1-14.

10. Bora K.S., Arora S., Shri R. Role of Ocimum basilicum L. in prevention of ischemia and reperfusion-induced cerebral damage, and motor dysfunctions in mice brain //Journal of ethnopharmacology. 2011. V. 137. №. 3, pp. 1360-1365.

11. Chavarria D. et al. Lessons from black pepper: piperine and derivatives thereof //Expert opinion on therapeutic patents. 2016. V. 26. №. 2, pp. 245-264.

12. De Monte P. et al. New insights into the biological properties of Crocus sativus L.: chemical modifications, human monoamine oxidases inhibition and molecular modeling studies //European journal of medicinal chemistry. 2014. V. 82, pp. 164-171.

13. de Moura J.P. et al. The blockade of transient receptor potential ankirin 1 (TRPA1) signalling mediates antidepressant-and anxiolytic-like actions in mice //British journal of pharmacology. 2014. V. 171. №. 18. P. 4289.

14. Fajemiroye J.O. et al. Anxiolytic and antidepressant like effects of natural food flavour (E)-methyl isoeugenol // Food \& function. 2014. V. 5. №. 8, pp. 1819-1828.

15. Fajemiroye J. O. et al. Treatment of anxiety and depression: medicinal plants in retrospect //Fundamental \& clinical pharmacology. 2016. V. 30. №. 3, pp. 198-215.

16. Ferlemi A.V. et al. Rosemary tea consumption results to anxiolytic-and antidepressant-like behavior of adult male mice and inhibits all cerebral area and liver cholinesterase activity; phytochemical investigation and in silico studies //Chemico-biological interactions. 2015. V. 237, pp. 47-57.

17. Fukui H., Toyoshima K., Komaki R. Psychological and neuroendocrinological effects of odor of saffron (Crocus sativus) //Phytomedicine. 2011. V. 18. №. 8, pp. $726-730$. 
18. Gamberini M.T. et al. Effects of the aqueous extract of Pimpinella anisum L. seeds on exploratory activity and emotional behavior in rats using the open field and elevated plus maze tests //Journal of ethnopharmacology. 2015. V. 168, pp. 45-49.

19. Gastón M.S. et al. Sedative effect of central administration of Coriandrum sativum essential oil and its major component linalool in neonatal chicks //Pharmaceutical biology. 2016. V. 54. №. 10, pp. 1954-1961.

20. Geromichalos G.D. et al. Saffron as a source of novel acetylcholinesterase inhibitors: molecular docking and in vitro enzymatic studies //Journal of agricultural and food chemistry. 2012. V. 60. №. 24, pp. 6131-6138.

21. Ghoshegir S.A. et al. Pimpinella anisum in the treatment of functional dyspepsia: A double-blind, randomized clinical trial //Journal of research in medical sciences: the official journal of Isfahan University of Medical Sciences. 2015. V. 20. №. 1. P. 13.

22. Gupta $\mathrm{S}$. et al. Modulation of transient receptor potential vanilloid subtype 1 (TRPV1) and norepinephrine transporters (NET) protect against oxidative stress, cellular injury, and vascular dementia //Current neurovascular research. 2014. V. 11. №. 2, pp. 94-106.

23. Gupta S., Sharma B. Pharmacological benefits of agomelatine and vanillin in experimental model of Huntington's disease //Pharmacology Biochemistry and Behavior. 2014. V. 122, pp. 122-135.

24. Healy D. The creation of psychopharmacology. Harvard University Press, 2009.

25. Hoffmann K.M. et al. Kampo Medicine: Evaluation of the Pharmacological Activity of 121 Herbal Drugs on GABAA and 5-HT3A Receptors //Frontiers in pharmacology. 2016. V. 7. P. 219.

26. Hosseinzadeh H., Noraei N.B. Anxiolytic and hypnotic effect of Crocus sativus aqueous extract and its constituents, crocin and safranal, in mice //Phytotherapy Research. 2009. V. 23. №. 6, pp. 768-774.

27. Huegel H.M. Brain food for Alzheimer-free ageing: focus on herbal medicines //Natural Compounds as Therapeutic Agents for Amyloidogenic Diseases. Springer International Publishing, 2015, pp. 95-116.

28. Ito N. et al. Antidepressant-like effect of 1-perillaldehyde in stress-induced depression-like model mice through regulation of the olfactory nervous system // Evidence-Based Complementary and Alternative Medicine. 2011. V. 2011.

29. Jäger A.K. et al. Screening of plants used in Danish folk medicine to treat depression and anxiety for affinity to the serotonin transporter and inhibition of MAO-A//Journal of ethnopharmacology. 2013. V. 145. №. 3, pp. 822-825.

30. Jangra A. et al. Piperine augments the protective effect of curcumin against lipopolysaccharide-induced neurobehavioral and neurochemical deficits in mice //Inflammation. 2016. V. 39. №. 3, pp. 1025-1038. 
31. Jawale A. et al. Reversal of diabetes-induced behavioral and neurochemical deficits by cinnamaldehyde //Phytomedicine. 2016. V. 23. №. 9, pp. 923-930.

32. Jayant S., Sharma B. M., Sharma B. Protective effect of transient receptor potential vanilloid subtype 1 (TRPV1) modulator, against behavioral, biochemical and structural damage in experimental models of Alzheimer's disease //Brain research. 2016. V. 1642. P. 397-408.

33. Jeon S.J. et al. Biflorin Ameliorates Memory Impairments Induced by Cholinergic Blockade in Mice //Biomolecules \& therapeutics. 2017. V. 25. №. 3. P. 249.

34. Karimzadeh F. et al. Anticonvulsant and neuroprotective effects of Pimpinella anisum in rat brain //BMC complementary and alternative medicine. 2012. V. 12. №. 1. P. 76.

35. Kasmaei H.D. et al. Effects of Coriandrum sativum Syrup on Migraine: A Randomized, Triple-Blind, Placebo-Controlled Trial //Iranian Red Crescent Medical Journal. 2016. V. 18. №. 1.

36. Kazemi S. et al. Cardamom supplementation improves inflammatory and oxidative stress biomarkers in hyperlipidemic, overweight, and obese pre-diabetic women: A randomized double-blind clinical trial//Journal of the science of food and agriculture. 2017.

37. Khalid Z. et al. Celery root extract as an inducer of mania induction in a patient on venlafaxine and St John's Wort //Postgraduate medicine. 2016. V. 128. №. 7, pp. 682-683.

38. Khazdair M.R. et al. The effects of Crocus sativus (saffron) and its constituents on nervous system: A review //Avicenna journal of phytomedicine. 2015. V. 5. №. 5. P. 376.

39. Kim D.S. et al. Alpha-pinene exhibits anti-inflammatory activity through the suppression of MAPKs and the NF- $\kappa \mathrm{B}$ pathway in mouse peritoneal macrophages //The American journal of Chinese medicine. 2015. V. 43. №. 04, pp. 731-742.

40. Kim Y.H., Park J.H. Vanillin and 4-hydroxybenzyl alcohol attenuate cognitive impairment and the reduction of cell proliferation and neuroblast differentiation in the dentate gyrus in a mouse model of scopolamine-induced amnesia // Anatomy \& Cell Biology. 2017. V. 50. №. 2, pp. 143-151.

41. Kocaadam B., Şanlier N. Curcumin, an active component of turmeric (Curcuma longa), and its effects on health //Critical reviews in food science and nutrition. 2017. V. 57. №. 13, pp. 2889-2895.

42. Koppula S., Choi D.K. Cuminum cyminum extract attenuates scopolamine-induced memory loss and stress-induced urinary biochemical changes in rats: a 
noninvasive biochemical approach //Pharmaceutical biology. 2011. V. 49. №. 7, pp. 702-708.

43. Laribi B. et al. Coriander (Coriandrum sativum L.) and its bioactive constituents //Fitoterapia. 2015. V. 103, pp. 9-26.

44. Lechtenberg M. et al. Quality and functionality of saffron: quality control, species assortment and affinity of extract and isolated saffron compounds to NMDA and $\sigma 1$ (sigma-1) receptors //Planta Medica. 2008. V. 74. №. 07, pp. 764-772.

45. Li G. et al. Synergistic antidepressant-like effect of ferulic acid in combination with piperine: involvement of monoaminergic system //Metabolic brain disease. 2015. V. 30. №. 6, pp. 1505-1514.

46. Li J. et al. Effects of L-3-n-butylphthalide on cognitive dysfunction and NR2B expression in hippocampus of streptozotocin (STZ)-induced diabetic rats //Cell biochemistry and biophysics. 2015. V. 71. №. 1, pp. 315-322.

47. Liu Q.F. et al. Coriandrum sativum suppresses A $\beta 42$-induced ROS increases, glial cell proliferation, and ERK activation //The American journal of Chinese medicine. 2016. V. 44. №. 07, pp. 1325-1347.

48. López V. et al. Exploring pharmacological mechanisms of lavender (Lavandula angustifolia) essential oil on central nervous system targets //Frontiers in pharmacology. 2017. V. 8. P. 280.

49. Lopresti A.L. Curcumin for neuropsychiatric disorders: a review of in vitro, animal and human studies //Journal of Psychopharmacology. 2017. V. 31. №. 3, pp. 287-302.

50. Lopresti A.L. Salvia (Sage): A review of its potential cognitive-enhancing and protective effects //Drugs in R\&D. 2017, pp. 1-12.

51. Lopresti A.L., Drummond P.D. Efficacy of curcumin, and a saffron/curcumin combination for the treatment of major depression: A randomised, double-blind, placebo-controlled study //Journal of affective disorders. 2017. V. 207, pp. 188-196.

52. Machado D.G. et al. Antidepressant-like effect of the extract of Rosmarinus officinalis in mice: involvement of the monoaminergic system // Progress in Neuro-Psychopharmacology and Biological Psychiatry. 2009. V. 33. №. 4, pp. 642-650.

53. Machado D.G. et al. Rosmarinus officinalis L. hydroalcoholic extract, similar to fluoxetine, reverses depressive-like behavior without altering learning deficit in olfactory bulbectomized mice//Journal of ethnopharmacology. 2012. V. 143. №. 1, pp. 158-169.

54. Malik J., Munjal K., Deshmukh R. Attenuating effect of standardized lyophilized Cinnamomum zeylanicum bark extract against streptozotocin-induced 
experimental dementia of Alzheimer's type //Journal of basic and clinical physiology and pharmacology. 2015. V. 26. №. 3, pp. 275-285.

55. Mao Q.Q. et al. Piperine reverses the effects of corticosterone on behavior and hippocampal BDNF expression in mice //Neurochemistry international. 2014. V. 74 , pp. 36-41.

56. Matsumura S. et al. Search for $\beta$-Secretase Inhibitors from Natural Spices // Natural product communications. 2016. V. 11. №. 4, pp. 507-510.

57. Mehta A.K. et al. The effect of the essential oil of Eugenia caryophyllata in animal models of depression and locomotor activity //Nutritional neuroscience. 2013. V. 16. №. 5, pp. 233-238.

58. Mohan M., Yarlagadda S., Chintala S. Effect of ethanolic extract of Coriandrum sativum L. on tacrine induced orofacial dyskinesia //Indian journal of experimental biology. 2015. V. 53. №. 5. P. 292.

59. Mosaffa-Jahromi M. et al. Effectiveness of Anise Oil for Treatment of Mild to Moderate Depression in Patients With Irritable Bowel Syndrome: A Randomized Active and Placebo-Controlled Clinical Trial // Journal of evidence-based complementary \& alternative medicine. 2017. V. 22. №. 1, pp. 41-46.

60. Muszyńska B. et al. Natural products of relevance in the prevention and supportive treatment of depression //Psychiatr. Pol. 2015. V. 49. №. 3, pp. 435 453.

61. Ng Q.X. et al. Clinical Use of Curcumin in Depression: A Meta-Analysis // Journal of the American Medical Directors Association. 2017. V. 18. №. 6, pp. 503-508.

62. Oboh G. et al. Essential oil from clove bud (Eugenia aromatica Kuntze) inhibit key enzymes relevant to the management of type- 2 diabetes and some pro-oxidant induced lipid peroxidation in rats pancreas in vitro //Journal of oleo science. 2015. V. 64. №. 7, pp. 775-782.

63. Panossian A. et al. Comparative study of Rhodiola preparations on behavioral despair of rats

64. Pengelly A. et al. Short-term study on the effects of rosemary on cognitive function in an elderly population //Journal of medicinal food. 2012. V. 15. №. 1, pp. 10-17.

65. Perveen T. et al. Repeated administration of Nigella sativa decreases 5-HT turnover and produces anxiolytic effects in rats // Pakistan Journal of Pharmaceutical Sciences. 2009. V. 22. №. 2.

66. Pourgholami M. H. et al. The fruit essential oil of Pimpinella anisum exerts anticonvulsant effects in mice //Journal of ethnopharmacology. 1999. V. 66. №. 2, pp. 211-215. 
67. Pourzaki M. et al. Preventive effect of Coriandrum sativum on neuronal damages in pentylenetetrazole-induced seizure in rats //Avicenna Journal of Phytomedicine. 2017. V. 7. №. 2. P. 116.

68. Rabbani M., Sajjadi S. E., Vaezi A. Evaluation of anxiolytic and sedative effect of essential oil and hydroalcoholic extract of Ocimum basilicum L. and chemical composition of its essential oil //Research in pharmaceutical sciences. 2015. V. 10. №. 6. P. 535.

69. Sampath S. et al. Holy basil (Ocimum sanctum Linn.) leaf extract enhances specific cognitive parameters in healthy adult volunteers: A placebo controlled study //Indian journal of physiology and pharmacology. 2015. V. 59. №. 1. P. 69.

70. Seyedemadi P. et al. The Neuroprotective Effect of Rosemary (Rosmarinus officinalis L.) Hydro-alcoholic Extract on Cerebral Ischemic Tolerance in Experimental Stroke //Iranian journal of pharmaceutical research: IJPR. 2016. V. 15. №. 4. P. 875.

71. Shahamat Z., Abbasi-Maleki S., Motamed S. M. Evaluation of antidepressant-like effects of aqueous and ethanolic extracts of Pimpinella anisum fruit in mice //Avicenna Journal of Phytomedicine. 2016. V. 6. №. 3. P. 322.

72. Shao Y. et al. Thymoquinone attenuates brain injury via an antioxidative pathway in a status epilepticus rat model//Translational Neuroscience. 2017. V. 8. №. 1, pp. 9-14.

73. Shoeb A. et al. Evaluation of antidepressant activity of vanillin in mice //Indian journal of pharmacology. 2013. V. 45. №. 2. P. 141.

74. Shojaii A., Abdollahi Fard M. Review of pharmacological properties and chemical constituents of Pimpinella anisum // ISRN pharmaceutics. 2012. V. 2012.

75. Silva N. R. Chocolate consumption and effects on serotonin synthesis //Archives of internal medicine. 2010. V. 170. №. 17, pp. 1608-1609.

76. Singh V. et al. Evaluation of anti-amnesic effect of extracts of selected Ocimum species using in-vitro and in-vivo models //Journal of ethnopharmacology. 2016. V. 193, pp. 490-499.

77. Song H. et al. Rosemary extract improves cognitive deficits in a rat's model of repetitive mild traumatic brain injury associated with reduction of astrocytosis and neuronal degeneration in hippocampus //Neuroscience letters. 2016. V. 622, pp. 95-101.

78. Taherian A.A., Vafaei A.A., Ameri J. Opiate system mediate the antinociceptive effects of Coriandrum sativum in mice//Iranian journal of pharmaceutical research: IJPR. 2012. V. 11. №. 2. P. 679.

79. Victoria F.N. et al. Involvement of serotoninergic and adrenergic systems on the antidepressant-like effect of E. uniflora L. leaves essential oil and 
further analysis of its antioxidant activity // Neuroscience letters. 2013. V. 544, pp. 105-109.

80. Wang H. et al. Protection effect of piperine and piperlongumine from Piper longum L. alkaloids against rotenone-induced neuronal injury // Brain research. 2016. V. 1639, pp. 214-227.

81. Waye A. et al. Canadian boreal pulp and paper feedstocks contain neuroactive substances that interact in vitro with GABA and dopaminergic systems in the brain //Science of the Total Environment. 2014. V. 468, pp. 315-325.

82. Xiang J. et al. L-3-n-butylphthalide improves cognitive impairment of APP/PS1 mice by BDNF/TrkB/PI3K/AKT pathway // International journal of clinical and experimental medicine. 2014. V. 7. №. 7. P. 1706.

83. Xu J. et al. Vanillin-induced amelioration of depression-like behaviors in rats by modulating monoamine neurotransmitters in the brain //Psychiatry research. 2015. V. 225. №. 3, pp. 509-514.

84. Xu Y. et al. Piperine potentiates the effects of trans-resveratrol on stress-induced depressive-like behavior: involvement of monoaminergic system and cAMP-dependent pathway // Metabolic brain disease. 2016. V. 31. №. 4. P. 837.

85. Yadav V. et al. Preventive potentials of piperlongumine and a Piper longum extract against stress responses and pain // Journal of traditional and complementary medicine. 2016. V. 6. №. 4, pp. 413-423.

86. Yao Y. et al. Cinnamic aldehyde treatment alleviates chronic unexpected stress-induced depressive-like behaviors via targeting cyclooxygenase- 2 in midaged rats //Journal of ethnopharmacology. 2015. V. 162, pp. 97-103.

87. Yi L. T. et al. Orthogonal array design for antidepressant compatibility of polysaccharides from Banxia-Houpu decoction, a traditional Chinese herb prescription in the mouse models of depression // Archives of pharmacal research. 2009. V. 32. №. 10. P. 1417.

88. Yu Y.M., Lin H.P., Chang W.P. Carnosic acid prevents the migration of human aortic smooth muscle cells by inhibiting the activation and expression of matrix metalloproteinase-9 // British journal of nutrition. 2008. V. 100. №. 4, pp. 731-738.

89. Zahra K., Khan M.A., Iqbal F. Oral supplementation of Ocimum basilicum has the potential to improves the locomotory, exploratory, anxiolytic behavior and learning in adult male albino mice // Neurological Sciences. 2015. V. 36. №. 1, pp. 73-78.

90. Zargar-Nattaj S.S. et al. The effect of Coriandrum sativum seed extract on the learning of newborn mice by electric shock: interaction with caffeine and diazepam //Psychology research and behavior management. 2011. V. 4. P. 13. 
91. Zhang L. et al. Effects of DL-3-n-butylphthalide on vascular dementia and angiogenesis //Neurochemical research. 2012. V. 37. №. 5, pp. 911-919.

92. Zhang L. et al. Trans-cinnamaldehyde improves memory impairment by blocking microglial activation through the destabilization of iNOS mRNA in mice challenged with lipopolysaccharide//Neuropharmacology. 2016. V. 110, pp. 503-518.

93. Zhang W.K. et al. Nutmeg oil alleviates chronic inflammatory pain through inhibition of COX-2 expression and substance P release in vivo //Food \& nutrition research. 2016. V. 60. №. 1. P. 30849.

\section{ДАННЫЕ ОБ АВТОРАХ}

Беккер Роман Александрович, магистр в области компьютерных наук, исследователь в области психофармакотерапии Университет им. Давида Бен-Гуриона в Негеве а/я 653, Беер-Шева, 8410501, Израиль rbekker1@gmail.com

Быков Юрий Витальевич, кандидат медицинских наук, ассистент кафедры анестезиологии, реаниматологии и скорой медицинской помощи Ставропольский Государственный Медицинский Университет ул. Мира, 310, г. Ставрополь, Ставропольский край, Российская Федерация yubykov@gmail.com

\section{DATA ABOUT THE AUTHORS}

Bekker Roman Aleksandrovich, M.Sc., Researcher Ben-Gurion University of the Negev P.O.B. 653, Beer-Sheva, 8410501, Israel rbekker1@gmail.com ORCID: 0000-0002-0773-3405 ResearcherID: J-7724-2016

Bykov Yuriy Vitalevich, $\mathrm{PhD}$, Assistant of the Department of Anesthesiology, Intensive Care and Emergency Medical Care Stavropol State Medical University 310, Mira Str., Stavropol, Russian Federation yubykov@gmail.com ORCID: 0000-0003-4705-3823 ResearcherID: K-1888-2016 